\title{
SISTEM INFORMASI IT-HELPDESK PADA UNIVERSITAS AMIKOM YOGYAKARTA BERBASIS WEB
}

\author{
Ali Mustopa \\ Sistem Informasi Universitas Amikom Yogyakarta \\ Jl. Ring Road Utara, Condong Catur, Depok, Sleman \\ e-mail: ali.m@amikom.ac.id ${ }^{1)}$
}

\begin{abstract}
ABSTRAK
IT Helpdesk merupakan sebuah unit layanan yang bertugas membantu mengatasi permasalahan terkait penggunaan fasilitas TIK di Universitas AMIKOM Yogyakarta. IT Helpdesk menyediakan beberapa bentuk layanan yang dapat dimanfaatkan oleh civitas akademik di Universitas AMIKOM Yogyakarta dalam menggunakan layanan TIK. Layanan unit ini diantaranya berupa instalasi, troubleshooting software, service dan maintenance komputer. Penelitian ini membahas tentang bagaimana pembangunan sistem informasi bagi user, konsumen dan manajamen IT Helpdesk. IT Helpdesk Universitas AMIKOM Yogyakarta saat ini telah memiliki sebuah sistem informasi yang mencakup pengelolaan registrasi data user dan keuangan. Namun, di sana belum terdapat sistem informasi yang memberikan informasi detail dari pihak konsumen, yang dapat dimanfaatkan oleh konsumen IT Helpdesk sendiri dalam melacak status pelayanan. Selain itu, sistem yang ada saat ini belum dapat menunjang kebutuhan manajemen dalam memantau dan mengevaluasi kinerja para teknisi. Hasil dari penelitian yaitu berupa sistem yang bisa memberikan informasi dengan secara cepat dan akurat kepada konsumen dan manajamen IT Helpdesk.
\end{abstract}

Kata Kunci: IT Helpdesk, layanan, Sistem Informasi

\begin{abstract}
IT Helpdesk is a service unit that is responsible to help in overcoming the problems related to the usage of ICT facilities at Universitas AMIKOM Yogyakarta. IT Helpdesk provides some form of services that can be utilized by academic community at Universitas AMIKOM Yogyakarta in usage of ICT services. This unit services include installation, troubleshooting software, service and computer maintenance. This research discusses about how information system development for user, consumer and manajamen IT Helpdesk. IT Helpdesk of Universitas AMIKOM Yogyakarta currently has an information system that includes the management of user registration and financial data. However, there is no information systems that provides detailed information from the consumer, which can be utilized by consumers IT Helpdesk itself in tracking the services status. Additionally, the current system has not been able to support management requirements in monitoring and evaluating the performance of technicians. The results of the research is a system that can provide information with a fast and accurate to the consumer and management of IT Helpdesk.
\end{abstract}

Keywords: Information System, IT Helpdesk, services

\section{PENDAhUluan}

$\mathrm{I}$ $\mathrm{T}$ Helpdesk merupakan sebuah unit layanan yang bertugas membantu mengatasi permasalahan terkait penggunaan fasilitas TIK di Universitas AMIKOM Yogyakarta, IT Helpdesk menyediakan beberapa bentuk layanan yang dapat dimanfaatkan oleh civitas akademik di Universitas AMIKOM Yogyakarta dalam menggunakan layanan TIK. Layanan unit ini diantaranya berupa instalasi, troubleshooting software, service dan maintenance komputer [1].

Ketersediaan layanan sistem informasi dapat menjadi sebuah kebutuhan yang dapat digunakan oleh IT Helpdesk [2]. Perancangan sistem informasi memungkinkan user mengakses data dan informasi lingkungan berdasarkan subsistem fungsional, dan juga dapat mengolah informasi secara baik, efektif serta efisien untuk menunjang keberhasilan dan kelancaran dalam proses pekerjaan.

Sistem informasiHelpdesk merupakan sistem manajemen untuk membantu menangani kebutuhan divisi/user terkait dengan pertanyaan, pelayanan, support teknis terhadap produk atau aplikasi \& jasa tertentu untuk memudahkan penelusuran terhadap tindakan penyelesaian yang dikoordinasi oleh suatu team [3].

IT Helpdesk Universitas AMIKOM Yogyakarta saat ini telah memiliki sebuah sistem informasi yang mencakup pengelolaan registrasi data user dan keuangan, akan tetapi pada aplikasi sistem informasi tersebut belum terdapat sistem yang memberikan informasi mendetail dari pihak konsumen, yang dapat dimanfaatkan oleh konsumen IT Helpdesk sendiri dalam melacak status pelayanan, sehingga konsumen masih harus datang langsung ke IT Helpdesk untuk mengetahui status pelayanan,dan juga sistem yang ada saat ini belum dapat menunjang kebutuhan manajemen dalam memantau dan mengevaluasi kinerja para teknisi [4]. 
Penambahan aplikasi ini dibuat dikarenakan masih terjadi masalah dalam pembagian kerja antara teknisi, dimana masih ada penumpukan pekerjaan antara satu teknisi dengan teknisi yang lain, dan masih adanya lempar tanggung jawab antara teknisi saat pihak manajamen melakukan evalusi kinerja, oleh karena itu diperlukanlah sebuah sistem informasi yang dapat membantu pihak manajemen dalam permasalahan tersebut.

\section{METODE}

Pada [5] dinyatakan bahwa untuk sistem pencarian informasi untuk menjadi sukses, ia harus memiliki kemampuan untuk menentukan peringkat hasil pencarian. Sebagai mesin pencari web yang paling sering digunakan dan dalam hal fungsi peringkat fungsi sistem yang ada paling maju, prinsip-prinsip mereka didasarkan pada dan strategi yang mereka gunakan dapat menguntungkan bila diterapkan pada konteks perpustakaan. Kami mengkategorikan faktor peringkat ke enam kelompok yang berbeda: 1 . statistik teks, 2. popularitas, 3. kesegaran, 4. lokalitas dan ketersediaan, 5. properti konten dan 6. latar belakang pengguna. Kami membahas konsep dasar dan asumsi faktor-faktor peringkat melibatkan dan menawarkan implementasi potensi dalam konteks perpustakaan. Praktek yang disarankan di sini adalah untuk perpustakaan untuk tidak hanya menerapkan dipilih faktor peringkat - sistem informasi perpustakaan yang ada sudah lakukan - tetapi untuk secara sistematis menguji faktor peringkat paling cocok untuk sistem mereka. Kami berdebat untuk tampilan pengguna-sentris pada peringkat, karena pada akhirnya, peringkat harus untuk kepentingan pengguna, dan preferensi pengguna mungkin berbeda-beda di konteks yang berbeda.

Campbell dan Grimshaw [6] membahas sikap yang dapat menyebabkan pengguna untuk menolak implementasi sistem informasi menggunakan teori didirikan dari psikologi sosial dan kognitif. Dikatakan bahwa pengguna yang tidak berpikir secara mendalam tentang sistem merupakan penyumbatan kunci dan bahwa sikap mereka sebagian besar didasarkan pada heuristik dan pengaruh perifer. Hasil studi secara luas disajikan di mana 28 heuristik dan pengaruh perifer yang umum mempengaruhi sikap pengguna diidentifikasi.

Pada [7] untuk menentukan kompetensi inti, untuk digunakan sebagai dasar untuk staf dan pelatihan, dan diperlukan untuk menyediakan sumber daya elektronik yang efektif (ER) untuk dukungan akses [7] desain atau metodologi atau pendekatan. Para penulis menganalisis 580 laporan masalah akses ER dalam sistem perpustakaan akademik besar untuk mengukur keterampilan tertentu yang diperlukan untuk penyelesaian masalah yang efektif. laporan masalah ditarik sama dari dua sistem pelaporan yang berbeda: satu menggunakan bentuk web dan e-mail dan menampilkan real-time interaksi pengguna lainnya. Paper ini menawarkan demonstrasi obyektif bahwa keterampilan yang mengarah ke keberhasilan dalam mendukung akses keterampilan komunikasi yang sama dihargai dalam layanan referensi dan bahwa mekanisme yang digunakan untuk menyediakan layanan referensi maya juga dapat digunakan untuk menangani masalah akses pengguna. Mengidentifikasi dan peringkat keterampilan ini memberikan struktur dan standar praktik terbaik untuk pelatihan yang berkesinambungan dan penilaian staf.

Pada penelitian [8] menyatakan bahwa sistem pendukung keputusan tanggap darurat (ERDSS) perlu untuk membantu pengambil keputusan untuk mengevaluasi rencana darurat dan pilih salah satu yang sesuai dalam keadaan darurat dengan mendukung sumber data tanggap darurat heterogen dan menyediakan pembuat keputusan akses ke pengetahuan penyelamatan darurat yang sesuai. Hal ini juga perlu memberikan layanan yang berbeda untuk memenuhi persyaratan. Apakah sistem tersebut efektif atau tidak tergantung pada kerangka itu didasarkan pada. Penelitian ini mengusulkan suatu kerangka ERDSS yang terdiri dari sepuluh modul fungsional: Layanan Darurat Helpdesk, Command dan Koordinasi Pusat, Rencana Darurat Manajemen, Bantuan Darurat Kebutuhan Manajemen, Emergency Keuangan Pengelolaan Anggaran, Organisasi Darurat dan Manajemen Kegiatan, Gudang Pengetahuan Emergency, Alarm Manajemen Darurat, dan Analisis masalah dan Manajemen. Studi kasus dilakukan pada manajemen darurat sistem pendukung keputusan Shanghai, sebuah EMDSS berdasarkan kerangka kerja ini dan diterapkan saat ini di Shanghai, Cina. Studi ini menunjukkan bahwa sistem kerangka ERDSS yang diusulkan dapat memberikan bimbingan teoritis dan praktis untuk merancang dan mengembangkan sistem tanggap darurat yang efektif.

Metode penelitian ini menggunakan Experiment Reasearch. Eksperimen sebagai suatu penelitian ilmiah dimana peneliti memanipulasi dan mengontrol satu atau lebih variabel bebas dan melakukan pengamatan terhadap variabel-variabel terikat untuk menemukan variasi yang muncul bersamaan dengan manipulasi terhadap variabel bebas tersebut. Lebih lanjut dijelaskan, variabel yang dimanipulasi disebut variabel bebas dan variabel yang akan dilihat pengaruhnya disebut variabel terikat. Selanjutntnya, Metode pengumpulan data yang digunakan dalam penelitian ini adalah sebagai berikut :

a. Observasi.

Teknik pengumpulan data dengan mengadakan penelitian dan peninjauan langsung terhadap permasalahan yang 
diambil.

b. Wawancara.

Dalam tahap ini mengadakan tanya jawab secara langsung dengan koordinator IT Helpdesk Universitas AMIKOM Yogyakarta.

\section{HASIL}

Analisis sistem merupakan tahap mempelajari dan mengidentifikasi suatu sistem yang selanjutnya dilakukan evaluasi terhadap sistem. Analisis sistem melibatkan sistem yang sedang berjalan atas dasar perbaikan terhadap sistem tersebut. Analisis aturan bisnis berisikan analisis aturan-aturan yang berlaku pada sistem yang sedang berjalan. Analisis aturan bisnis dibagi menjadi dua bagian yaitu berdasaarkan fakta dan kebutuhan. Berikaut ini merupakan aturan bisnis berdasarkan fakta pada sistem informasi IT Helpdesk di Universitas AMIKOM Yogyakarta:

1. Koordinator IT Helpdesk memantau kinerja teknisi berdasarkan laporan lisan

2. User pada IT Helpdesk Universitas AMIKOM Yogyakarta yaitu sebagai operator.

3. User sebagai operator bertugas untuk menginput data-data konsumen IT Helpdesk.

Selanjtunya, terdapat juga aturan bisnis berdasarkan kebutuhan pada sistem informasi IT Helpdesk di Universitas AMIKOM Yogyakarta sebagai berikut:

1. Koordinator IT Helpdesk memantau kinerja teknisi berdasarkan laporan secara tercetak berdasarkan data-data yang objektif.

2. Koordinator IT Helpdesk memiliki hak untuk menentukan kriteria dan sub kriteria untuk menentukan bobot penilaian teknisi.

3. User pada IT Helpdesk Universitas AMIKOM Yogyakarta memiliki dua jabatan sekaligus, yaitu sebagai operator dan admin.

4. User sebagai operator bertugas untuk menginput data-data konsumen IT Helpdesk.

5. User sebagai admin bertugas untuk mengelola data-data konsumen, teknisi dan layanan IT Helpdesk.

Dari aturan bisnis berdasarkan fakta dan kebutuhan di atas dapat disimpulkan bahwa semua aturan yang ada sudah cukup dan dapat memenuhi kebutuhan untuk pembangunan sistem informasi IT Helpdesk di Universitas AMIKOM Yogyakarta. Analisis masalah merupakan salah satu langkah yang dilakukan dalam menganalisis sistem dengan tujuan menemukan masalah yang dialami agar selanjutnya dapat dibuat solusi terbaik untuk mengatasi permasalahan tersebut. Beberapa masalah yang dialami IT Helpdesk Universitas AMIKOM Yogyakarta dalam memberikan informasi:

1. Belum tersediaanya pengelola data kinerja para teknisi IT Helpdesk dengan baik?

2. Belum tersediaanya pelayanan informasi kepada para konsumen IT Helpdesk?

3. Belum tersediaanya sistem informasi yang memberikan informasi kepada manajamen di IT Helpdesk Universitas AMIKOM Yogyakarta tentang kinerja para teknisi?

Pengguna merupakan elemen utama dalam berjalannya sebuah sistem. Pengguna pada aplikasi sistem informasi dapat dikategorikan sebagai administrator dan pelanggan. Setiap pengguna harus memiliki kemampuan mengoperasikan komputer dan mempunyai pengetahuan mengenai internet. Tabel berikut akan menjelaskan lebih detail mengenai analisis pengguna aplikasi sistem informasi yang dibangun dan pengguna yang terlibat dalam penggunaan aplikasi sistem informasi. Pada Tabel 1 diuraikan beberapa tugas pengguna dalam dimensi pelaku, tanggung jawab, hak akses, tingkat pendidikan, kemampuan dan pengalaman. Dalam hal ini pengguna dibagi menjadi 2 jenis yaitu administrator dan operator. Kebutuhan fungsional ini mencakup hal-hal yang dapat dilakukan sistem. 
TABEL I

DAFTAR KEBUTUHAN FUNGSIONAL

\begin{tabular}{ll}
\hline \multicolumn{1}{c}{ Pengguna } & \multicolumn{1}{c}{ Administrator } \\
\hline Pelaku & Koordinator IT Helpdesk Universitas AMIKOM Yogyakarta \\
Tanggung Jawab & Menentukan petugas yang terlibat dalam sistem sistem informasi. \\
Hak Akses & Mengelola data petugas dan data konsumen \\
Tingkat Pendidikan & Minimal S1 \\
Kemampuan & Menguasai komputer, mampu mengoperasikan aplikasi sistem \\
& informasi, memiliki pengetahuan tentang internet. \\
Pengalaman & - \\
Jenis Pelatihan & Cara menggunakan aplikasi \\
& \\
Pengguna & Operator \\
Pelaku & Kasir atau bagian lain yang ditentukan koordinator. \\
Tanggung Jawab & Menangani transaksi pelayanan dan pengolahan data. \\
Hak Akses & Mengelola data pelayanan, mengelola data master. \\
Tingkat Pendidikan & SMA dan sederajat. \\
Kemampuan & Menguasai komputer, mampu menangani transaksi penjualan, \\
& mampu mengoperasikan aplikasi dan paham tentang internet. \\
Pengalaman & Mampu menangani transaksi pelayanan. \\
Jenis Pelatihan & Cara menggunakan aplikasi. \\
\hline
\end{tabular}

Setelah gambaran umum didefinsisikan, kebutuhan fungsional dan non fungsional dapat didokumentasikan menggunakan use case Diagram. Diagram ini menggambarkan fungsi sistem dari sudut pandang pengguna eksternal dan dalam cara dan terminologi yang mereka pahami serta sistem ini mendeskripsikan kebutuhan fungsional yang telah didefinisikan. Pada Gambar 1 ditampilkan diagram use case untuk dokumentasi dari kebutuhan fungsional dan non fungsional. Pada Gambar tersebut terdapat 3 pengguna sistem atau aktor yaitu Operator, Administrator, dan Konsumen. Aktor-aktor tersebut menggunakan sistem sesuai yang didefinisikan dalam kebutuhan fungsional. Setiap aktor atau pengguna berinteraksi dengan masing-masing kebutuhan fungsional yang dikelompokkan dalam sub sistem. Input data keluhan yang dilakukan konsumen dilanjutkan ke lihat data keluhan oleh operator sedangkan administratror dapat melakukan olah data terhadap operator, teknisi, dan perangkat.

Perancangan logika merupakan tahap yang akan mengungkapkan kebutuhan bisnis pada sistem yang dibangun. Perancangan ini tetap menggunakan pemodelan UML (Unified Modeling language) yang berorientasi objek. Awal tahap ini adalah memodelkan langkah proses atau aktivitas dari sistem. Pemodelan aktivitas dari sistem ini menggunakan diagram aktivitas (activity diagram). Diagram aktivitas tersebut menggambarkan langkah-langkah dari use case yang didefinisikan sebelumnya. Pada Gambar 2 ditampilkan Activity Diagram Registrasi Konsumen. Registrasi konsumen ini dimulai sistem yang menampilan halaman berisi form biodata. Kolom isian form ini disikan oleh konsumen dan disetujui penyimpananannya sehingga sistem menyimpan data konsumen pada basisdata.

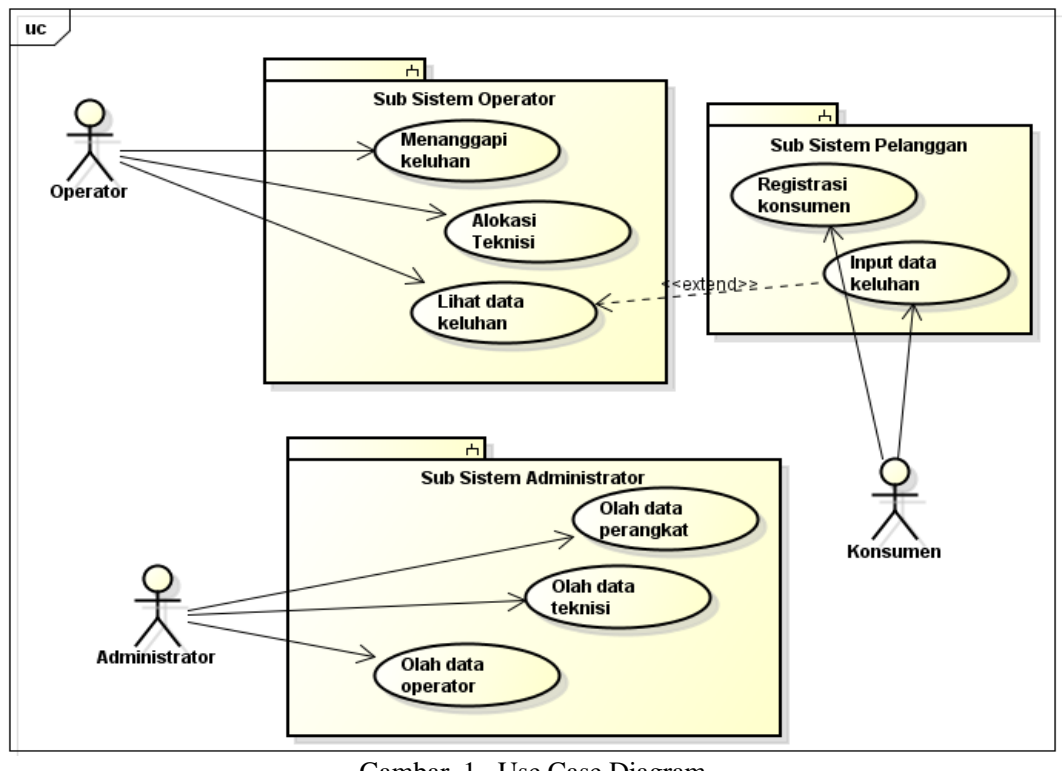

Gambar. 1. Use Case Diagram 
Pada Gambar 3 ditampilkan activity diagram input data keluhan. Diagram ini diawali dengan adanya form isian keluhan konsumen yang ditampilkan sistem. Konsumen mengisikan data keluhan kemudian menyetujui penyimpanan data tersebut. Sistem melakukan penyimpanan data keluhan pada basisdatanya. Prosedur ini merupakan uraian dari case input data keluhan pada sub sistem konsumen seperti ditunjukka pada Gambar 1. Beberapa activity diagram ini merepresentasikan alur logika dari prosedur jalannya sistem. Hal-hal yang digambarkan pada diagram ini tidak menyangkut aspek teknis dan mengandung istilah sederhana yang mudah dimengerti oleh pengguna. Hal ini karena diagram ini digunakan pengembang sistem untuk menggali kebutuhan fungsional yang lebih dalam sehingga mendapatkan beberapa kebutuhan fungsional yang sesuai dengan pengguna. Selain itu penggguna juga telah mengetahui gambaran logika sebelum sistem selesai dibangun. Hal ini menyebabkan pengguna lebih mudah mempelajari penggunaan sistem dan mempercepat sistem mencapai user friendly.

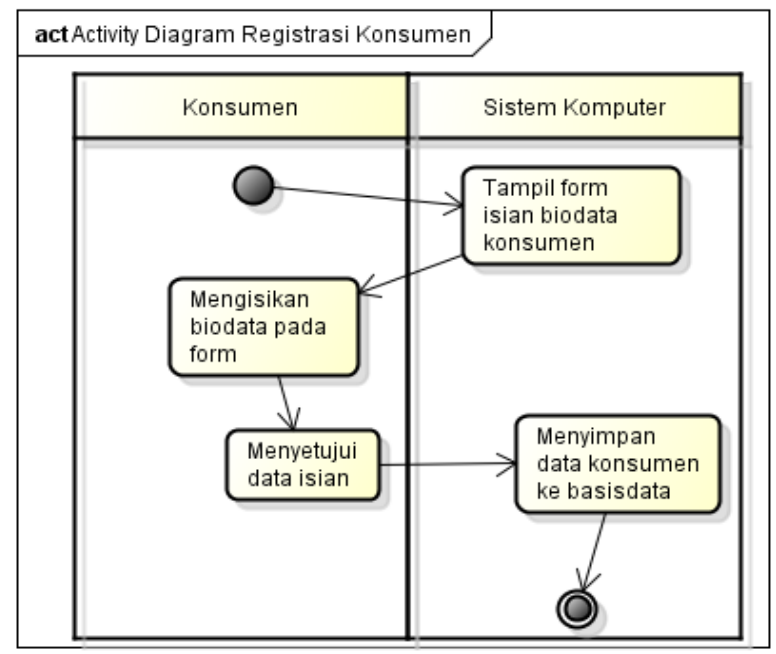

Gambar. 2. Activity Diagram Registrasi Konsumen

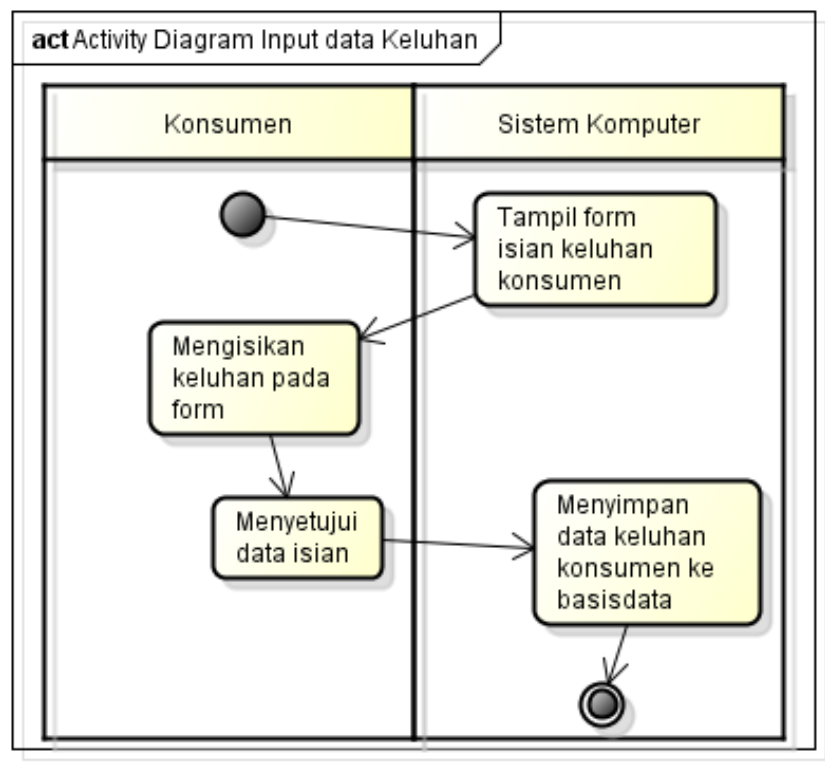

Gambar. 3. Activity Diagram Input Data Keluhan

Pada Gambar 4 ditampilkan activity diagram mengenai alokasi teknisi. Alokasi teknisi ini merupakan representasi dari sub sistem pada use case diagram yang ditunjukkan pada Gambar 1. Awalnya, sistem menampilkan daftar teknisi. Selanjutnya, operator memilih salah satu daftar teknisi untuk didelegasikan menangani permasalahan dari keluhan konsumen. Kemudian, operator merelasikan teknisi dengan beberapa keluhan konsumen untuk proses penanganannya. Operator juga melakukan penjadwalan terhadap tindak lanjut penanganan permasalah. Setelah proses alokasi teknisi selesai dilakukan dan disetujui perubahannya, sistem menyimpan data alokasi ini ke basis data. Data yang disimpan ini dapat dipanggil kembali dalam bentuk daftar. 


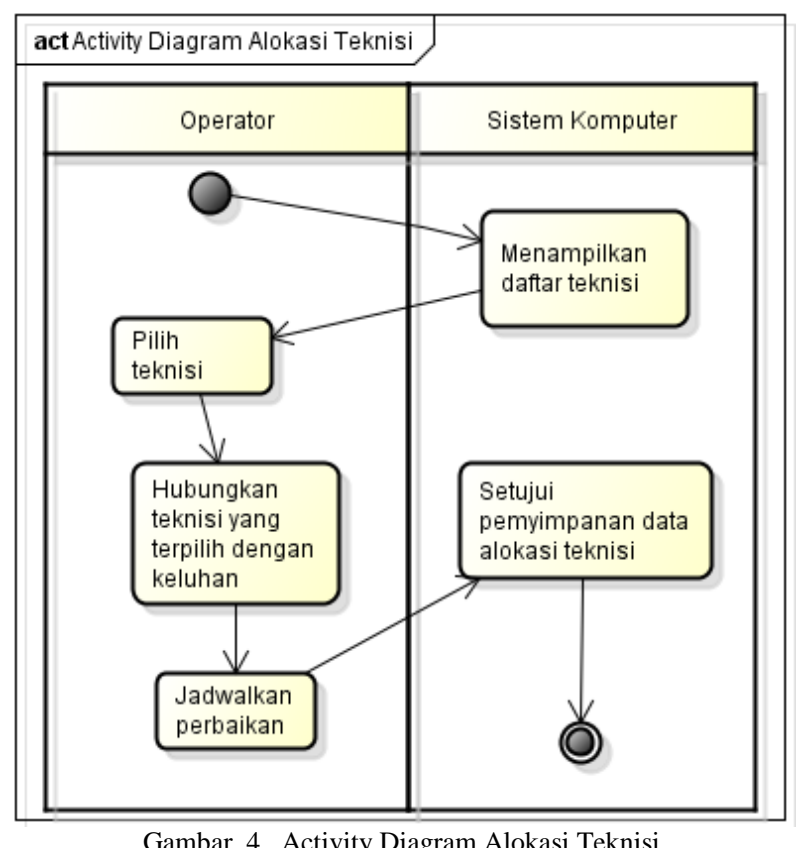

Setelah menganalisis menggunakan diagram aktivitas, langkah selanjutnya adalah mengidentifikasi entitas. Entitas yang terlibat dalam sistem ini direpresentasikan menggunakan kelas. Kelas (entitas) yang telah teridentifikasi adalah Teknisi, Konsumen, Perangkat, dan Brand. Gambar struktur kelas yang teridentifikasi tersebut ditunjukkan pada Gambar 5. Kelas yang didefinisikan pada diagram ini berupa kelas entitas yang merupakan abstraksi dari data-data yang akan disimpan dalam basisdata. Pada diagram ini terdapat kelas induk yaitu Akun dan menghasilkan 2 kelas anak yaitu konsumen dan teknisi. Kelas konsumen berelasi dengan kelas perangkat. Selanjutnya, kelas perangkat berelasi dengan kelas brand. Beberapa kelas ini menghasilkan objek melalui proses instanisasi. Pada konsep pengembangan berorientasi objek, objek-objek hasil instanisasi ini saling berinteraksi satu sama lainnya sehingga menghasilkan proses pada sistem. Interaksi yang terjadi berdasarkan 3 aspek orientasi objek yaitu pengkapsulan, pewarisan, dan polimorfisme.

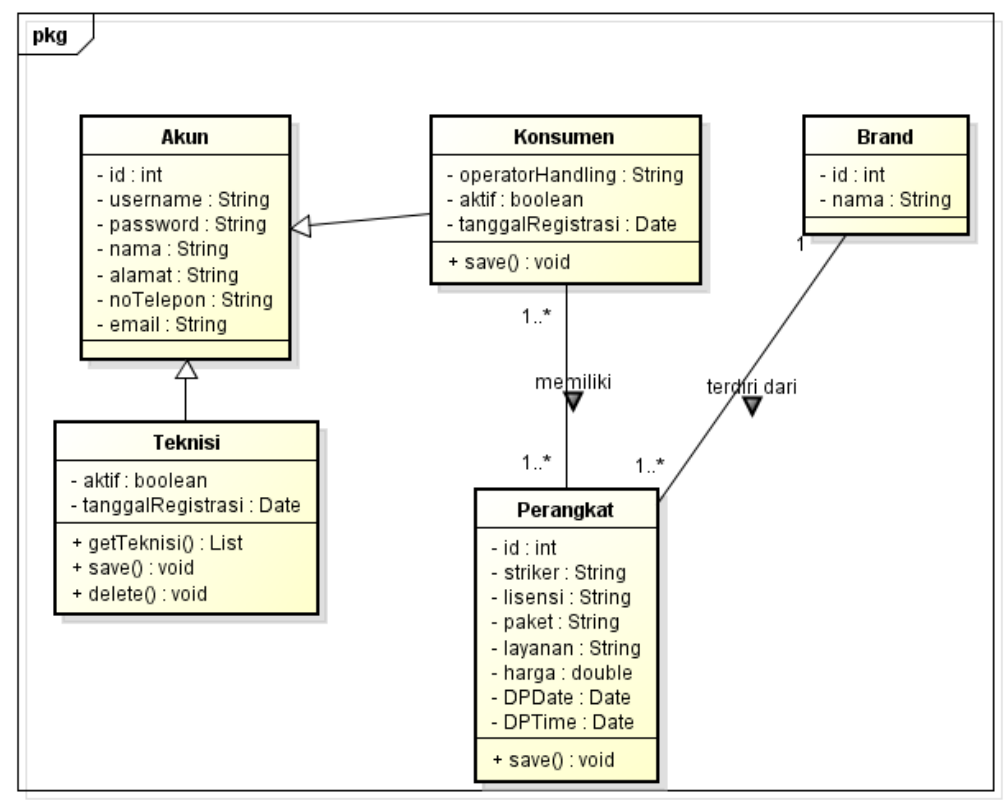

Gambar. 5. Class Diagram

Perancangan fisik difokuskan pada konsentrasi implementasi atau teknis sistem. Tahap perancangan fisik pada penelitian ini menggunakan metode berorientasi objek yang menyertakan analisis berorientasi objek untuk memperbaiki definisi kebutuhan objek dan memperbaiki perancangan baru yang menghasilkan objek yang spesifik. Tahap ini terdiri dari identifikasi perilaku kelas dan rancangan antarmuka pengguna. Identifikasi ini berguna untuk mengetahui secara detail dari interaksi beberapa kelas. Identifikasi mengenai detail interaksi ini sangat diperlukan saat implementasi ke kode program. Hal ini akan memdahkan programmer mengimplementasikan karena sudah ada gambaran proses-proses yang terurut. Tahap ini menggunakan sequence 
diagram untuk menampilkan interaksi kelas berdasarkan urutannya. Berikut ini beberapa sequence diagram yang telah dirancang. Pada Gambar 6 merupakan representasi dari prosedur registrasi konsumen seperti yang digambarkan pada Gambar 2. Namun, diagram ini lebih mengarah ke aspek teknis dan ditujukan ke kontruktor sistem dan memuat beberapa istilah teknis. Pada Gambar 6 menghasilkan kelas KonsumenController yang memuat algoritma registrasi konsumen. Awalnya obyek hasil instanisasi kelas KonsumenController menampilkan halaman form isian biodata konsumen menggunakan method showPage(). Kemudian, konsumen mengisikan data-data sesuai dengan kolom isian yang disediakan dan menyetujui penyimpanan. Objek KonsumenController mengirimkan pesan ke obyek konsumen berupa method save(). Pengiriman pesan ini berarti pemanggilan method yang dilakukan objek konsumenController terhadap method save() yang dimiliki objek konsumen.

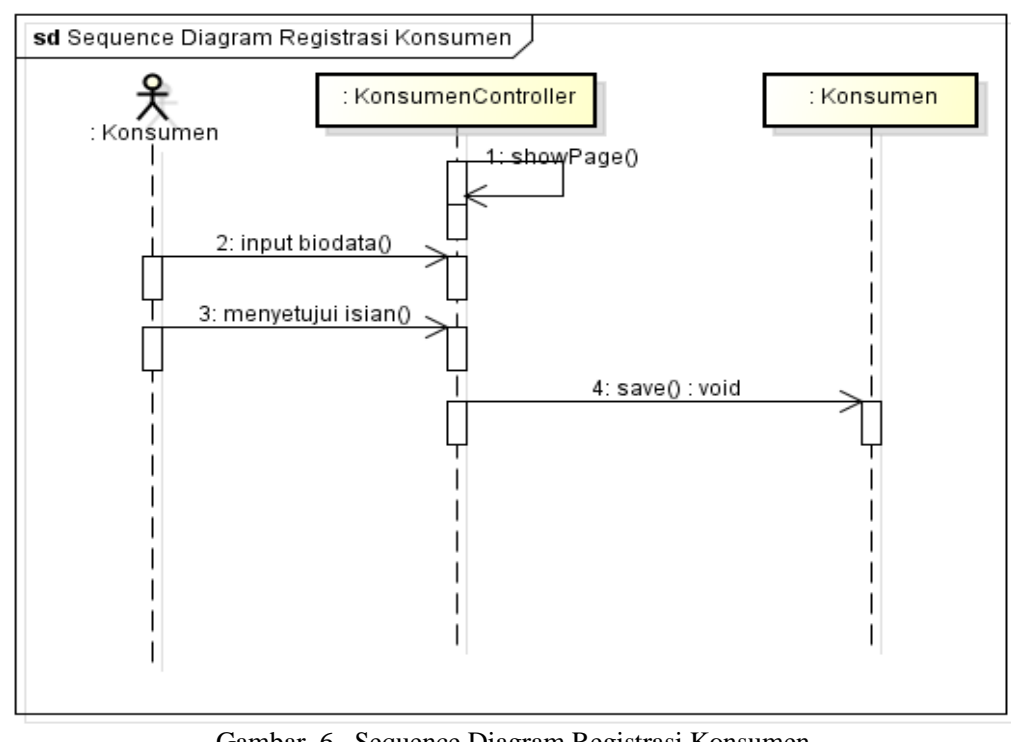

Gambar. 6. Sequence Diagram Registrasi Konsumen

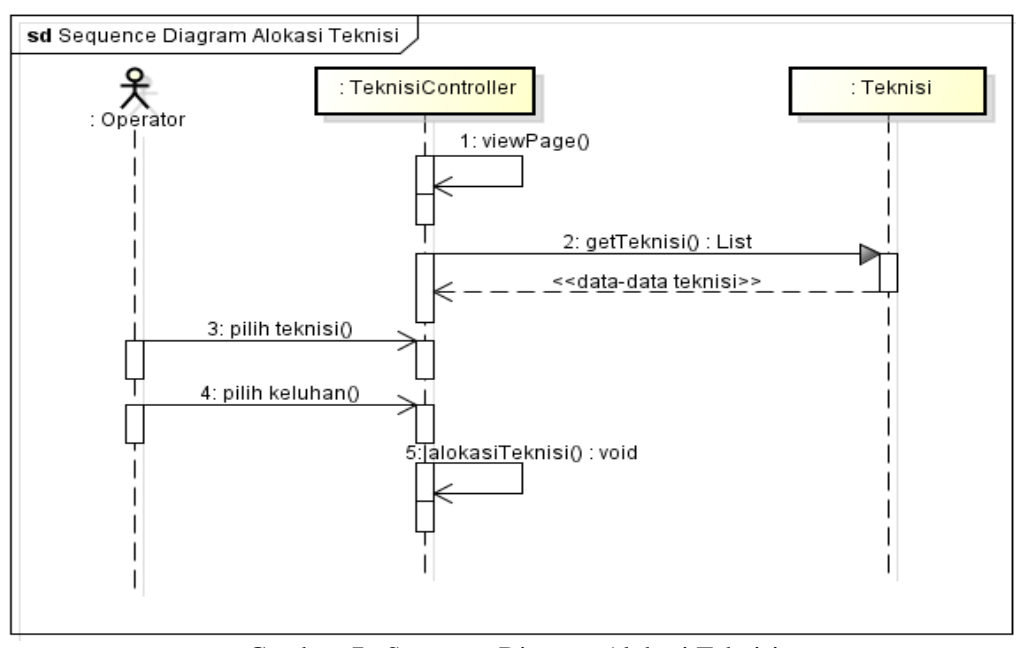

Gambar. 7. Sequence Diagram Alokasi Teknisi

Pada Gambar 7 ditampilkan sequence diagram Alokasi Teknisi. Diagram ini menghasilkan kelas TeknisiController yang memuat proses atau algoritma alokasi teknisi. Awalnya, obyek hasil instanisasi kelas TeknisiController menampilkan form isian untuk alokasi teknisi dengan memanggil methodnya sendiri yaitu viewPage(). Selanjutnya, objek TeknisiController memanggil method getTeknisi() dari objek teknisi. Hal ini menyebabkan data-data teknisi ditampilkan ke operator. Selanjutnya, operator memilih teknisi yang telah ditampilkan dalam bentuk daftar. Selain itu, operator juga memilih daftar keluhan konsumen dan direlasikan dengan teknisi yang dipilih sebelumnya. objek teknisiController melakukan alokasi teknisi dengan memanggil methodnya sendiri yaitu alokasiTeknisi().

Pada aplikasi dibutuhkan suatu antarmuka agar pengguna dapat berinteraksi dengan sistem pada aplikasi tersebut. Pengguna akan merasa nyaman berinteraksi dengan sistem tergantung pada perancangan antarmuka yang dilakukan. Tahap ini akan merancang beberapa antarmuka pengguna agar dapat berinteraksi dengan mudah terhadap sistem. Antarmuka tersebut membentuk suatu hirarki yang digambarkan dengan peta situs/sitemap pada Gambar 8. Pada Gambar 8 terdapat banyak tampilan yang membangun sistem ini. Saat pengguna membuka 
website soal online ini, pengguna masuk pada beranda.

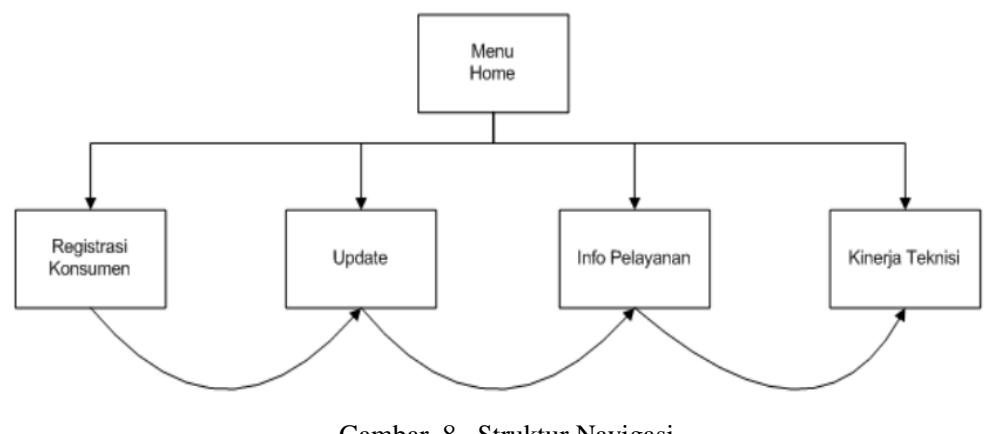

Gambar. 8. Struktur Navigasi

\section{PEMBAHASAN}

Implementasi sistem ini menggunakan bahasa pemrograman PHP 5.6.8 dan sistem manajemen basisdata MySQL 5.6.24. Tahap implementasi merupakan tahap konstruksi perangkat lunak, tahap kelanjutan dari kegiatan perancangan sistem. Tahap ini merupakan tahap dimana sistem siap untuk dioperasikan, yang terdiri dari penjelasan mengenai lingkungan implementasi, dan implementasi program. Pada Tabel 2 ditampilkan deskripsi mengenai tampilan user, manajemen dan konsumen yang telah dibangun. Pada tampilan tersebut memiliki beberapa fitur dan dapat digunakan.

Pengujian perangkat lunak dilakukan untuk menguji sistem yang dibangun dengan tujuan untuk menemukan kesalahan atau kekurangan pada perangkat lunak yang diuji. Pengujian bermaksud untuk mengetahui perangkat lunak yang dibangun telah memenuhi kriteria yang sesuai dengan tujuan perancangan perangkat lunak tersebut. Pengujian perangkat lunak ini menggunakan metode blackbox. Pengujian blackbox berfokus pada persyaratan fungsional perangkat lunak. Pengujian blackbox ini fokus pada pengujian Alpha. Pada Tabel II terdapat beberapa deskripsi menu mengenai fungsinya. Menu yang dijelaskan pada Tabel II memuat Registrasi Konsumen, Update Konsumen, Konsumen status dan kinerja Teknisi. Selanjutnya, pada Tabel III di jelaskan mengenai rencana pengujian dari beberapa fitur dalam keempat menu tersebut. Pengujian ini dilakukan setelah sistem yang dibangun selesai. Kemudian pada Tabel IV terdapat uraian dari rencana pengujian halaman User. Rencana pengujian untuk antar muka, manajemen dan konsumen, halaman administrator, dan halaman user memiliki kemiripan rencana.

TABEL II

IMPLEMENTASI ANTAR MUKa USER, MANAJAMEN DAN KONSUMEN

\begin{tabular}{|c|c|c|}
\hline No & Menu & Deskripsi \\
\hline 1. & Registrasi Konsumen & Fasilitas yang disediakan bagi user untuk registrasiasi konsumen \\
\hline 2. & Update Konsumen & Berfungsi untuk user mengupdate status layanan konsumen \\
\hline 3. & Konsumen Status & Fasilitas bagi konsumen yang akan melacak status layanan \\
\hline 4. & Kinerja Teknisi & $\begin{array}{l}\text { Menu informasi bagi manajamen untuk melihat data-data kinerja dan } \\
\text { penilaian terhadap teknisi. }\end{array}$ \\
\hline
\end{tabular}

TABEL III

RENCANA PENGUJIAN HALAMAN ADMINISTRATOR

\begin{tabular}{lll}
\hline No & \multicolumn{1}{c}{ Menu } & \multicolumn{1}{c}{ Deskripsi } \\
\hline 1. & Registrasi Konsumen & Fasilitas yang disediakan bagi user untuk registrasiasi konsumen \\
2. & Update Konsumen & Berfungsi untuk user mengupdate status layanan konsumen \\
3. & Konsumen Status & Fasilitas bagi konsumen yang akan melacak status layanan \\
4. & Kinerja Teknisi & $\begin{array}{l}\text { Menu informasi bagi manajamen untuk melihat data-data kinerja dan } \\
\text { penilaian terhadap teknisi. }\end{array}$ \\
\hline
\end{tabular}


TABEL IV

RENCANA PENGUJIAN HALAMAN USER

\begin{tabular}{lll}
\hline No & \multicolumn{1}{c}{ Menu } & \multicolumn{1}{c}{ Deskripsi } \\
\hline 1. & Registrasi Konsumen & Fasilitas yang disediakan bagi user untuk registrasiasi konsumen \\
2. & Update Konsumen & Berfungsi untuk user mengupdate status layanan konsumen \\
3. & Konsumen Status & Fasilitas bagi konsumen yang akan melacak status layanan \\
4. & Kinerja Teknisi & Menu informasi bagi manajamen untuk melihat data-data kinerja dan \\
& & penilaian terhadap teknisi. \\
\hline
\end{tabular}

TABEL V

PENGUJIAN LOGIN ADMINISTRATOR

\section{Kasus dan Hasil Uji (Data Benar)}

$\begin{array}{ll}\text { Data Masukkan } & \text { Yang Diharapkan } \\ \text { Username: admin } & \begin{array}{l}\text { Mengisi data email pada kolom } \\ \text { isian email. }\end{array} \\ \text { Password: admin123 } & \begin{array}{l}\text { Mengisi password pada kolom isian } \\ \text { password. }\end{array}\end{array}$

Kasus dan Hasil U.ji (Data Salah)

Data Masukkan
Memasukkan data username dan
password yang tidak terdaftar.
Username: administrator
Password: 123456
Username: (kosong)
Password: (kosong)

\section{Yang Diharapkan}

Menampilkan pesan kesalahan

"login gagal. email atau password salah"

\begin{tabular}{|c|c|}
\hline Pengamatan & Kesimpulan \\
\hline $\begin{array}{l}\text { Dapat mengisi kolom isian email } \\
\text { pada kolom isian email. }\end{array}$ & $\begin{array}{l}{[\sqrt{ }] \text { Diterima }} \\
{[\quad] \text { Ditolak }}\end{array}$ \\
\hline $\begin{array}{l}\text { Dapat mengisi kolom isian password pac } \\
\text { kolom isian password. }\end{array}$ & $\begin{array}{l}{[\sqrt{ }] \text { Diterima }} \\
{[\quad] \text { Ditolak }}\end{array}$ \\
\hline
\end{tabular}

Pengamatan

Kesimpulan

Dapat menampilkan pesan kesalahan $\quad[\sqrt{ }]$ Diterima "login gagal. Email atau password salal [ ] Ditolak

\begin{tabular}{|l|l|l|l}
\hline Username: (kosong) & Menampilkan pesan kesalahan & Dapat menampilkan pesan kesalahan & {$[\sqrt{ }]$ Diterima }
\end{tabular}

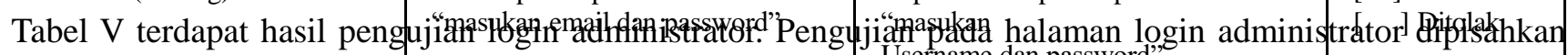
menjadi 2 yaotu kasus dan hasil uji untuk input data benar dan input data saląh. Uraian masing-masing jenis data

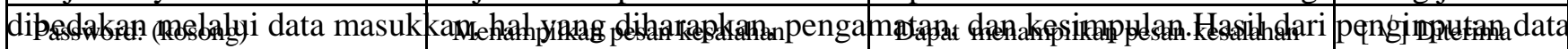

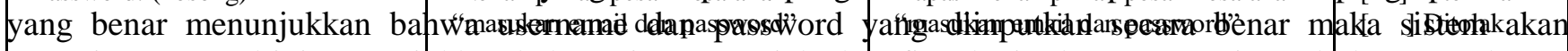
menerimanya. Hal ini menunjtkkan bahwa sistem menjatankan fitur login dengan sesuai untuk data yang benar. Kemudian, data yang salah akan dihasilkan beberapa pesan kesalahan login bahkan data username dan password dalam kondisi kosong. Hal ini menyebabkan sistem menolak data yang tidak diisikan. Adanya perilaku ini menunjukkan sistem berjalan sesuai dengan menolah data login yang tidak sesuai.

Pada Tabel VI ditampilkan hasil pengujian data kategori. Pengujian ini juga dibedakan menjadi 2 yaitu kasus dan hasil uji data benar dan data yang salah. Setiap kategori ini diuraikan jenis data masukan, hal yang diharapkan, pengamatan dan kesimpulan. Awal pengujian dimulai dengan menginputkan data benar berupa nama teknisi Anto. Hal yang diharapkan muncul dengan perilaku dapat mengisi data kategori pada kolom isian nama kategori selain itu dapat mengisi kategori dalam kolom isian juga. Jika diinputkan data yang salah maka muncul pesan kesalaman "nama teknisi harus diisi" dan "gagal, teknisi telah digunakan". Hal ini menunjukkan sistem menolak data yang salah. Jadi, hasil pengujian ini menunjukkan fitur data kategori berjalan dengan sesuai menolak data yang salah. 
TABEL VI

PENGUJian DATA Kategori

Kasus dan Hasil Uji (Data Benar)

Tambah

Data Masukkan

Nama teknisi: Anto

Kasus dan Hasil Uji (Data Salah)

Tambah

Data Masukkan

Nama teknisi: (kosong)

Mengisikan nama teknisi denga nama teknisi yang telah digunakan, contoh.

Nama teknisi: Anto

Kasus dan Hasil Uji (Data Benar)

Edit

Data Masukkan

Nama teknisi: Anto

Yang Diharapkan

Pengamatan

Kesimpulan

Kolom isian nama teknis terisi Kolom isian nama teknisi terisi dengan benar. $[\sqrt{ }]$ Diterima

[ ] Ditolak

Kasus dan Hasil Uji (Data Salah)

Edit

Data Masukkan

Nama teknisi: (kosong)
Mengisi data kategori pada kolom isian nama kategori.

Dapat mengisi kolom isian kategori pada kolom isian nama kategori.

\section{Pengamatan}

Dapat menampilkan pesan kesalahan "nama teknisi harus diisi".

$[\sqrt{ }]$ Diterima

Dapat menampilkan pesan kesalahan "gagal, nan $[\sqrt{ }]$ Diterima teknisi telah digunakan".

[ ] Ditolak "gagal, nama teknisi telah
Menampilkan pesan kesalahan
[ ] Ditolak digunakan". $[\sqrt{ }]$ Diterima

] Ditolak

\section{Yang Diharapkan}

Tampil pesan kesalaha "nama teknisi harus diisi".

\section{Pengamatan}

Dapat menampilkan pesan kesalahan "nama teknisi harus diisi".
Kesimpulan

$[\sqrt{ }]$ Diterima

[ ] Ditolak

\section{SIMPULAN}

Terdapat beberapa kesimpulan dari penelitian yang telah dilakukan ini. Beberapa kesimpulan tersebut adalah sebagai berikut:

1. Sistem informasi yang telah dibangun sudah dapat memberikan pengelolaan data kinerja para teknisi bagi pihak manajemen IT Helpdesk sehingga pembagian kerja antar satu teknisi dengan teknisi lainnya sama pada bobot kerjanya masing-masing.

2. Sistem informasi yang telah dibangun dapat memberikan pengelolaan informasi kepada IT Helpdesk dalam memberikan informasi pelayanan kepada para konsumen.

3. Sistem informasi memiliki fitur-fitur yang telah berjalan sesuai dengan spesifikasi kebutuhan yang telah didefinisikan.

\section{REFERENSI}

[1] R.Pressman, "Software Engineering: A Practitioner's Approach", 2010.

[2] R. Addy, "Effective Service IT Management to ITIL and Beyond", New York: Springer, 2007.

[3] C. Lahti, S. Lanza, R. Peterson, "IT Compliance Using COBIT and Open Source Tools" Rockland: Syngress, 2005

[4] T. Ali, "Implementasi Tim Helpdesk Universitas", Yogyakarta: GECC, 2008.

[5] C. Behnert, D. Lewandowski, "Ranking Search Results in Library Information Systems — Considering Ranking Approaches Adapted From Web Search Engines", Journal of Academic Librarianship, 2015, Vol. 41 Issue 6, p725-735. 11p.

[6] R.H. Campbell, M. Grimshaw, "User Resistance to Information System Implementations: A Dual-Mode Processing Perspective", Information Systems Management. 2016, Vol. 33 Issue 2, p179-195. 17p.

[7] T. Resnick, A. Ugaz, N. Burford, "E-Resource Helpdesk Into Virtual Reference: Identifying Core Competencies, Reference Services Review. 2010, Vol. 38 Issue 3, p347-359. 13p.

[8] S. Shan, L. Wang, L. Li, Y. Chen, "An Emergency Response Decision Support System Framework for Application in E-Government, Information Technology \& Management, 2012, Vol. 13 Issue 4, p411-427. 17p. 